\title{
Paleoenvironmental Reconstruction of Glaciovolcanism in the Cascades of the Pacific Northwest: Implications of Potential Habitable Environments on Mars
}

\author{
Chase T Glenister and Barry I Cameron \\ Department of Geosciences, University of Wisconsin-Milwaukee
}

\begin{abstract}
The interaction between volcanic processes and glacial ice is termed glaciovolcanism and is a process that is prevalent on Earth and potentially once prevalent on Mars. Such processes are dynamic, forming potentially habitable environments under glacial ice. This work will attempt to describe the glaciovolcanic deposits at the Crazy Hills and Lone Butte in central Washington and evaluate the potential habitability of these glaciovolcanoes. The identification of pillow lavas and thick hyaloclastite beds point to the hosting glacier being at least $300 \mathrm{~m}$ thick, although precise estimation is not possible at this time. X-ray fluorescence results show that the two provinces shared a magmatic source deep in the mantle and evolved separately to form the Crazy Hills basalt and Lone Butte basaltic andesite. The identification of putative biogenic alteration textures in the pillow rims of the Crazy Hills basalt indicates a stronger potential for habitable conditions in a glaciovolcanic environment.
\end{abstract}

\section{Introduction}

The interaction between glacial ice and volcanic processes- often termed glaciovolcanism- can be a prevalent feature in volcanically-dominated regions hosting alpine glaciers or ice sheets, such as Iceland, British Columbia, and Antarctica (Smellie \& Edwards, 2016). These phenomena can create a wide variety of features, producing hydrothermal pools to constructing steep-sided, flattopped edifices called tuyas. The unusual characteristics of tuyas are due to the confining environment beneath a hosting ice deposit (Russell, Edwards, Porritt, \& Ryane, 2014). Crucially, these features often preserve evidence of their glaciovolcanic origin, allowing reconstruction of the eruption environment. Basaltic tuyas will often have characteristic lithofacies with pillow lavas comprising the initial deposits to form in a glaciovolcanic lava-based eruption (Jakobsson \& Gudmundsson, 2008). As the edifice continues to erupt into the overlying ice, meltwater is produced and either flows out of the growing cavity or creates a meltwater chamber around the edifice (Russell et al., 2014). Once the edifice erupts high enough into the overlying ice, the pressure is no longer high enough to prevent fracturing of the lava once it meets the water, which produces a fractured glass called hyaloclastite instead of pillow lava (Smellie \& Edwards, 2016). Hyaloclastites continue to accumulate as the eruption progresses until magma reaches the surface of the glacier or ice sheet. There is often a transitional zone in the lithofacies that shifts from hyaloclastite deposits to subaerial lava flows. This transition is called the passage zone, and is often used as an indicator for the thickness of the ice sheet the edifice erupted into (Skilling, 2009).

Significantly, the meltwater chamber that forms from a glaciovolcanic eruption has an abundance of heat, liquid water, and nutrients derived from volcanic processes that could sustain a thriving microbial community (Cousins et al., 2013; Cousins and Crawford, 2011). Numerous edifices present on Mars in the Sisyphi Montes region, near Mars' southern pole, are purported to be glaciovolcanoes (Ghatan \& Head, 2002). Establishing the eruptive history of terrestrial edifices and confirming the habitability of these environments would allow for better understanding of Martian glaciovolcanic systems and the potential for life on Mars. This work will attempt to draw comparisons between several glaciovolcanic edifices present in the Pacific Northwest of the US and purported glaciovolcanoes on Mars to constrain the paleo-environment and habitability of these Martian features (Ackiss et al., 2018; Ghatan and Head, 2002).

We are grateful for support provided by the Wisconsin Space Grant Consortium and the Department of Geosciences, UW Milwaukee and permissions given from the Gifford Pinchot National Forest. This project would not have been possible without this support. 


\section{Geologic Background}

With the exception of a few studies (Bacon \& Lanphere, 2006; Lescinsky \& Fink, 2000; Schmidt \& Grunder, 2009), glaciovolcanism remains a relatively obscure process in the Pacific Northwest, with several potentially glaciovolcanic edifices relatively understudied (Wilson \& Russell, 2018). The Pacific Northwest has had its landscape defined by abundant volcanic activity in the form of the Cascades, a range of arc volcanoes erupting magma influenced by the subducting Juan de Fuca plate (O'Hara, Karlstrom, \& Ramsey, 2020). The Cascadian volcanism would have interacted with the Cordilleran ice sheet and various alpine glaciers during the numerous glacial maximums that the region has hosted (Booth, Troost, Clague, \& Waitt, 2003; Wilson \& Russell, 2018). The Hayden Creek Glaciation (0.19 ma) was one such event, hosting the subglacial edifices Lone Butte and the associated Crazy Hills in southern Washington (Figure 1) (Hammond, 1987). Lone Butte is a conical tuya with an extent of $2.5 \mathrm{~km}^{2}$ composed of calcalkaline basalt, with abundant olivine phenocrysts. Hammond (1987) demonstrates that the basal deposits are palagonitized hyaloclastites, with hyaloclastite surge deposits and foreset-bedded pillow breccia

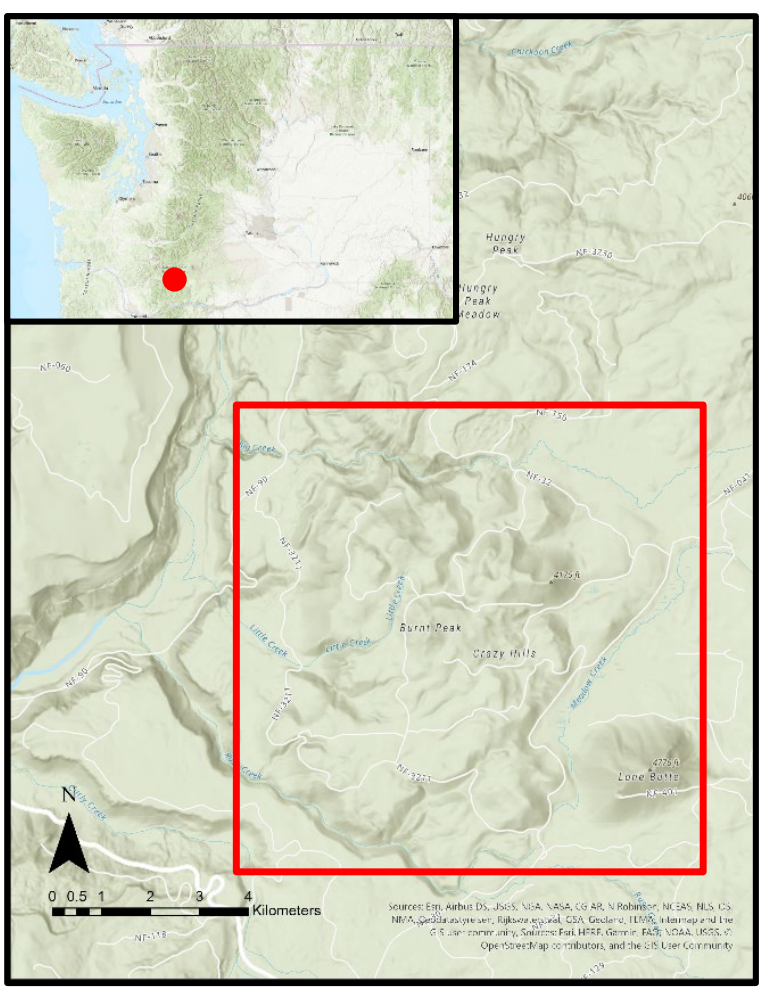

Figure 1- Location of Lone Butte and the Crazy Hills. Lone Butte is the smaller feature in the SE portion of the red box, while the Crazy Hills occupies much of the western half of the box. Inset map shows site location relative to Washington.

overlying, all of which would have been capped by a deltaic lava flow. Later glaciations would heavily eroded this capping lava flow, removing it almost entirely from the edifice. After the cessation of the Lone Butte eruption, the Crazy Hills glaciovolcanic province began to erupt (Hammond, 1987). The Crazy Hills are a series of what are called moberg hills, or mounds of palagonitized hyaloclastite overlying pillow lavas composed of tholeiitic basalt, with a generally vesicular texture and abundant plagioclase and olivine phenocrysts (Wilson and Russell 2018).

Mars is a predominately volcanic planet, with much of the volcanism occurring during its early history in the Noachian and petering out towards the end of the Hesperian (Ackiss, Horgan, Seelos, Farrand, \& Wray, 2018; Bibring et al., 2006). The cold Martian climate and the planet's variable obliquity have in the past produced extensive ice deposits not only at its poles, but even at the equator (Lanagan, McEwen, Keszthelyi, \& Thordarson, 2001). The amalgamation of abundant volcanism and Mars' propensity for producing extensive ice features suggests that glaciovolcanism may be a more prevalent process on Mars than previously thought (Ackiss et al., 2018; C. R. Cousins et al., 2013; Claire R. Cousins \& Crawford, 2011; Ghatan \& Head, 2002; Scanlon, Head, Wilson, \& Marchant, 2014). Several features near Mars' south pole are currently interpreted to be tuyas due to their flat tops and steep sides, and tropical glaciers (around the Martian equator) likely once interacted with deposits at Arisia Mons (Ghatan \& Head, 2002; Scanlon et al., 2014). 
Glaciovolcanic environments are currently considered potentially hospitable locations for extraterrestrial life owing to the warm, wet environment with an abundance of nutrients (C. R. Cousins et al., 2013; Claire R. Cousins \& Crawford, 2011). The common glaciovolcanic features identified on Mars provide the opportunity to assess Martian paleoclimate and the habitability of these glaciovolcanic terranes.

\section{Field and Laboratory Methods}

Stratigraphic analysis was undertaken in Summer of 2021 to document the glaciovolcanic lithofacies and record critical transitions from pillow lavas to pillow-brecciated flows to hyaloclastites. Field observations have documented the critical changes in environmental conditions during deposition of volcanic products. Samples of glassy rock were be collected from each edifice for laboratory analysis. Sampling focused on all lithofacies including glassy pillow rims, hyaloclastite, passage zones, and capping subaerial lava flows. Glassy pillow rims and altered hyaloclastite were also be collected to evaluate possible preservation of ichnofossils and other biosignatures.

X-Ray Fluorescence (XRF) analysis was conducted to obtain major and minor element concentrations of the sampled deposits. Samples were broken into smaller pieces which were then powdered with a tungsten carbide mortar and pestle in a Rocklabs shatterbox. The sample powders were dried overnight at $105^{\circ} \mathrm{C}$, after which a split of each sample was ashed in a muffle furnace at $1050^{\circ} \mathrm{C}$ to determine the loss-on-ignition percentage (LOI). Precisely 1.000 gram of each sample was mixed with precisely 10.000 grams of a $49.75 \mathrm{c} \%$ lithium tetraborate- $49.75 \%$ lithium metaborate- $0.5 \%$ lithium bromide flux. This mixture is then fused using a Claisse M4 fluxer into glass beads, which are then analyzed using a Bruker S4 Pioneer WD-XRF following the methods of McHenry et al. (2017). The resulting major, minor, and trace element concentrations were then plotted using the IgPET software.

In addition, samples were selected to produce $4.5 \mathrm{~cm} \mathrm{x} 2.5 \mathrm{~cm}$ billets that were sent to Grindstone Laboratories to create thin sections. Samples were selected for their hypothesized preservation potential of any microbial biosignatures and the occurrence of in situ glass. The thin sections were evaluated with a Leica DM750P polarizing microscope for evidence of putative biogenic alteration and more information on the petrological characteristics of the rock.

\section{Field Observations}

Lone Butte Much of Lone Butte is covered in dense rainforest, with the notable exception of an old quarry on the south-western corner of the edifice. The quarry outcrop consists of a scree slope leading up to a $\sim 8 \mathrm{~m}$ thick deposit of weathered hyaloclastite. A large portion of the upper hyaloclastite deposits contains various pillow fragments and breccia, with dark lobes present throughout the bottom of the hyaloclastite layer. The hyaloclastite deposit is largely weathered white to yellow, with the darker lobes hosting a whiter coating. These lobes are often fragmented and hackly, primarily composed of pillow breccia and pseudopillows. At the southernmost exposure of the outcrop is another dark lobe composed of actual pillow lava, with the most prominent pillow about three and a half feet wide.

While the rest of Lone Butte is heavily weathered and densely forested, several prominent outcroppings are present along the northeastern ridge of the edifice. Thick hyaloclastite beds $(\sim 5$ 
to $15 \mathrm{~m}$ ) are exposed along the lower portion of the ridge, with exposed rock often heavily weathered and covered with moss and lichen. Alignment of the glass fragments was observed on several of the exposures present, but for the most part is absent. Further up the ridge is a lightly weathered feeder dike that would have produced the eventual capping deltaic flow (Hammond, 1987). The matrix was light grey with no vesiculation and hosted olivines and plagioclase phenocrysts throughout. The very top of Lone Butte is a thin, heavily oxidized ridge composed largely of scoria with a vesicularity of $\sim 20 \%$.

Crazy Hills The associated Crazy Hills is a series of moberg hills with a scoria cone named Burnt Peak overlying the glaciovolcanic units (Hammond, 1987). The subaerial lava flows associated with Burnt Peak are basaltic rock lightly weathered to grey-orange, with plagioclase, olivine, and pyroxene phenocrysts throughout fresh material. Several quarries throughout the Hills dig far enough into the moberg hills to expose pristine pillow basalt piles. The southernmost exposure of pillow basalt (Stop 13, Hammond 1987) has small scree slope leads up to the base of a substantial basaltic pillow pile approximately $15 \mathrm{~m}$ thick. The pillows here can vary in size from a $0.33 \mathrm{~m}$ to $1.33 \mathrm{~m}$ wide and consist of vesicular basalt (vesicularity $\sim 20 \%$ ) with plagioclase and olivine phenocrysts. While the deposits here are fresh, the glassy rind on the exterior of these pillows have started weathering to a tan to white coating.

Overlying the pillow lava are hyaloclastite deposits that have been weathered grey to a tan orange. The hyaloclastite can occasionally feature layering in fresher outcrops, with layers typically being around $4 \mathrm{~cm}$ thick. Hyaloclastite beds also contain glass and pillow fragments throughout, although these fragments can concentrate at the border of each layer. Other quarries show a similar stratigraphy but have an increased abundance of grey-yellow-orange palagonitized glass. Also present at the Crazy Hills are opalized hyaloclastite deposits, which occur as pale grey to white deposits that have the appearance of an off-white sandstone.

Outcrops at higher elevations in the Hills are largely hyaloclastite deposits that can exhibit alternation between coarse pillow fragments and finer hyaloclastite material, often resulting in several horizons in the deposits. These deposits are often largely altered to palagonite and heavily weathered. The higher elevations of the Crazy Hills interior plays host to an oblique sill that intruded into hyaloclastite deposits. The intrusion is heavily fractured and weathered to yellowgrey, although fresh material is dark and vesicular $(\sim 25-30 \%)$ with plagioclase and olivine phenocrysts. The contact between the sill and the country rock resulted in the baking of the country rock, but in some locations it has produced a glassy, vesicular $(\sim 30-40 \%)$ deposit with crystalline material that is likely pepperite.

\section{Results}

X-ray fluorescence Major and minor element results show that the Crazy Hills are composed primarily of basalt, while Lone Butte is composed of basaltic andesite. A negative trend is observed in the $\mathrm{MgO}$ vs. $\mathrm{SiO}_{2}$ content of the Crazy Hills Basalt (CHB), varying from 6.3-8.7 

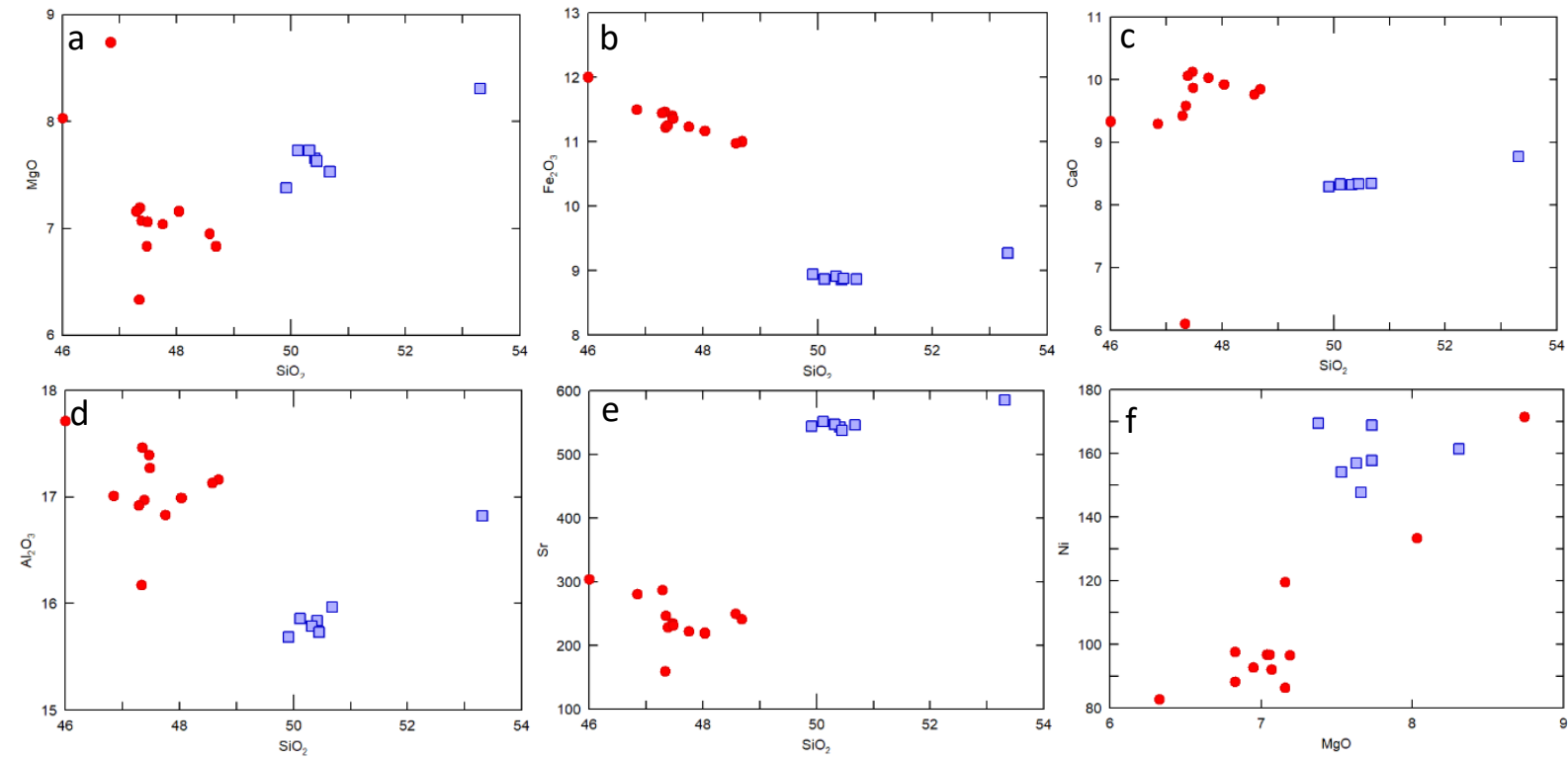

Figure 2- Notable trends obtained from XRF results for Lone Butte (LBBA) and the Crazy Hills (CHB). Red circles are the Crazy Hills and blue squares are Lone Butte. a) $\mathrm{MgO}$ vs. $\mathrm{SiO}_{2}$ shows a negative trend for the $\mathrm{CHB}$ but a positive one for LBBA. b) A negative trend is present for both provinces for $\mathrm{Fe}_{2} \mathrm{O}_{3}$ vs. $\mathrm{SiO}_{2}$. c) Both CHB and LBBA exhibit positive trends in $\mathrm{CaO}$ vs. $\mathrm{SiO}_{2}$. d) $\mathrm{CHB}$ exhibits a negative trend in $\mathrm{Al}_{2} \mathrm{O}_{3}$ vs. $\mathrm{SiO}_{2}$ while LBBA shows a positive trend. e) CHB has much lower Sr values than the LBBA. f) Both provinces exhibit high Ni concentrations, suggesting a mantle source for CHB and LBBA.

wt $\%$. The Lone Butte basaltic andesite (LBBA) has a positive trend with $\mathrm{MgO}$ content, which varies from $7.5-8.3 \mathrm{wt} \%$.

Both the CHB and LBBA exhibit a negative trend with $\mathrm{Fe}_{2} \mathrm{O}_{3}$, varying from 11- $12 \mathrm{wt} \%$ and 8.9$9.3 \mathrm{wt} \%$, respectively (Figure 2b). Positive trends in $\mathrm{CaO}$ vs. $\mathrm{SiO}_{2}$ are present with $\mathrm{CHB}$ containing 6.1-10.1 $\mathrm{wt} \%$ and LBBA containing 8.3-8.8 wt\% (Figure 2c), while a negative $\mathrm{Al}_{2} \mathrm{O}_{3}$ trend is present in the $\mathrm{CHB}$ with concentrations of $16.2-17.5 \mathrm{wt} \%$. A positive $\mathrm{Al}_{2} \mathrm{O}_{3}$ trend is present in the LBBA with concentrations of 15.7-16.0 wt\% (Figure 2d).

Sr values are high in the LBBA, varying from 538-585 ppm. Sr values in the CHB are much lower, varying from 159-304 ppm (Figure 2e). CHB and LBBA both have high Ni concentrations, from $83 \mathrm{ppm}$ in the CHB to $169 \mathrm{ppm}$ in the LBBA (Figure 2f).

Thin section observations The largest abundance of fresh glass comes from the Crazy Hills, mainly located in the rims of the pillow lavas. The occurrence of glass in the pillow basalt is highest at the surface of the pillow basalt; less than two centimeters into the pillow and the pillow becomes almost entirely crystalline. Focusing on the outer two centimeters of various pillows, evidence of putative biogenic alteration (PBA) can be found throughout the predominately glassy areas. The PBA present in the Crazy Hills pillow rims can occur as various morphologies, many of which have been described in the pillow rims of mid-ocean ridge pillow basalts in Fisk and McLoughlin (2013). These morphologies can include granular alteration (Figure 3A) and buds 

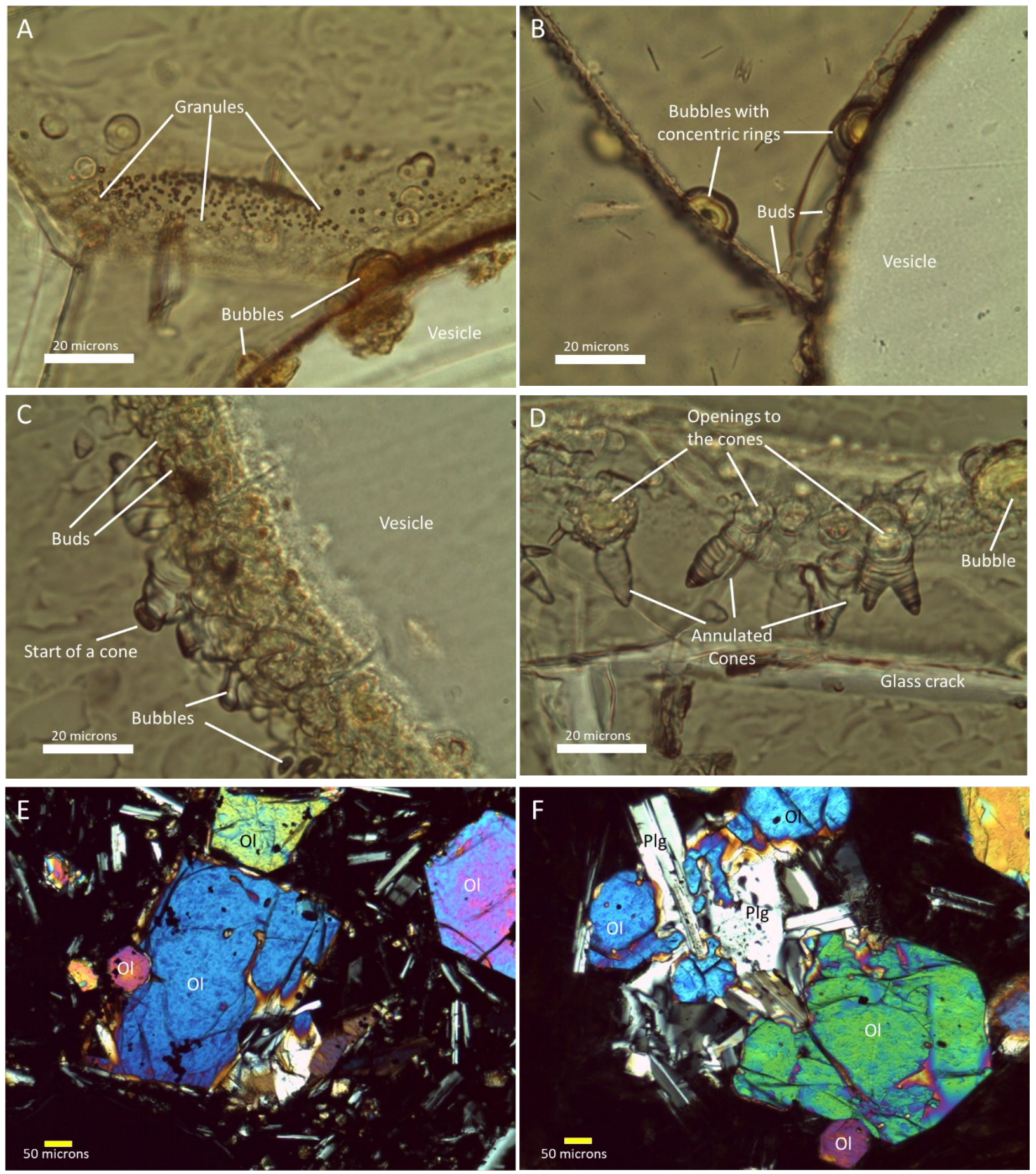

Figure 3- (A-D): Various forms of PBA encountered in the pillow rims of the Crazy Hills. (E\&F): Representative images of the state of olivines at Lone Butte and the Crazy Hills. A) Hundreds of tiny dots in the center of the image would be granular alteration, while the larger mounds at the edge of the vesicle would be bubbles. B) Bubble located at the edge of a vesicle and along a crack, with concentric rings in both. Smaller buds are also present. C) Clusters of bubbles and buds occurring along a vesicle edge, with an annulated cone that had started to form furthest from the vesicle. D) Several annulated cones that are intruding into the thin section, with their openings exposed. E) Olivines from Lone Butte tend to occur as subhedral to anhedral masses. F) Olivines from the Crazy Hills can be subhedral to anhedral and can contain resorption textures.

and bubbles along cracks in the glass and vesicles (Figure 3B\&C), with numerous variations 
thereof. Several examples of what appears to be an annulated conical intrusion into the glass is not described in the paper above and may represent a new form of PBA (Figure 3C\&D). These conical intrusions often have lateral grooves throughout the sides of the intrusions. While glass has been found at Lone Butte, the pseudopillows and the pillow at the Lone Butte quarry do not have glass attached to the rock; the glass is found relation to fresher pieces of the hyaloclastite.

Petrographically, the CHB and LBBA are somewhat similar- both contain plagioclase and olivine hosted in a largely amorphous matrix. The plagioclase crysts present can occur as euhedral to anhedral crystals, although the plagioclase will also occur as anhedral amalgamations (Figure 3F). Olivines will rarely occur as euhedral, often appearing subhedral to largely resorbed anhedral crysts (Figures 3E\&F).

\section{Discussion}

Lone Butte From field observations, it is clear that much of the Lone Butte edifice has been eroded away by glacial activity, leaving the core of the volcano after the ice body's last retreat. The peak of this core rises to an elevation of $1,457 \mathrm{~m}$ and the edifice itself is $430 \mathrm{~m}$ tall (Hammond, 1987). What is exposed of what remains is composed of hyaloclastite deposits, which suggests that these deposits were above the $300 \mathrm{~m}$ threshold to form pillow basalt (Stevenson, Smellie, McGarvie, Gilbert, \& Cameron, 2009). As the capping lava flow of the original tuya was not preserved, it is difficult to estimate the thickness of the hosting ice body from the morphology of Lone Butte alone. The oxidized scoria at the top of Lone Butte could represent the passage zonethe interaction between the erupting lava and the thinning ice would have produced scoria that the final lava flows would have covered. If we inferred that the scoria represents a part of the passage zone, then Lone Butte would have begun to breach the surface of an overlying glacier that would be a little more than $430 \mathrm{~m}$ thick. However, due to the amount of erosion and biological activity on the edifice this tentative estimation of the glacier thickness needs to be verified by another method- likely through measuring water contents with FT-IR.

XRF results show the evolution of the LBBA away from a Crazy Hills-like parental magma, which would have been fed by a deep mantle source (Figures $2 \mathrm{a} \& \mathrm{f}$ ). High $\mathrm{Sr}$ values point to calc-alkaline deposits forming at Lone Butte. When observing the Lone Butte lavas evolving away from a Crazy Hills-like parent, it seems likely that the two provinces share a source that would have migrated from Lone Butte to the Crazy Hills.

Both clinopyroxene and plagioclase are remaining in the chamber, while iron oxides are fractionating out of the chamber (Figures $2 b, c, \& d$ ). The rock under thin section is largely composed of olivine and plagioclase phenocrysts surrounded by plagioclase microlites (Figure $3 \mathrm{E})$.

Crazy Hills The presence of abundant pillow piles indicates that these products were formed under at least 300m of ice (Stevenson et al. 2009). At several of the Crazy Hills quarries, the pillow mounds transition to hackly hyaloclastite, indicating the eruption passed the $300 \mathrm{~m}$ threshold and started forming hyaloclastite. However, there is no indication in the facies present that the Crazy Hills ever breached the surface of its hosting glacier, making determination of the ice thickness not possible for the Crazy Hills at this time. Further work involving FT-IR 
measurements of water contents in the pillow rims would indicate much more about the thickness of the overlying glacier.

Major and minor element data show olivine fractionating out of the Crazy Hills magma chamber (Figures 2a\&d). The CHB also shows several of the same trends as the LBBA, which include the iron oxide fractionating out from the magma chamber as well as high Ni contents showing a mantle source (Figures 2b\&f). Lower Sr contents suggest a more tholeiitic lava, but the slight negative trend could indicate some instability with the plagioclase in the sample. This instability is not apparent petrographically (Figure 2e). The partial resorption of olivine suggests changing conditions before and potentially during eruption (Figure 3F). The Crazy Hills is younger than Lone Butte, but has erupted more mafic lava. This indicates that magma mixing likely caused by mafic recharge to the shared reservoir made the Crazy Hills more $\mathrm{MgO}$ rich and Si poor than Lone Butte. Resorption present in Crazy Hills olivine would represent this change in conditions.

The PBA present in the pillow rims occurs most as granular alteration, which often ends up altering much of the vesicle or crack (Figure 3A). Granular alteration often coincides with the buds and bubbles that form along cracks and vesicle walls, with the buds and bubbles occurring as solitary features or in clusters along cracks and vesicle walls (Figures 3B\&C). The conical intrusions typically co-occur with the buds and bubbles, with some buds showing a distinctly wider base than others (Figure 3C\&D). Any branching is rare (is occurring in Figure 3D), with the cones/buds mostly restricted to stout, singular features. While PBA can occur on the very edge of the pillow rim, very few examples are found near the edge. This may have to do with the preservation potential of the glass being higher closer to the interior of the pillow lava, as the exterior of the pillow would be subject to a variety of conditions and weathering regimes.

There are several alternative explanations to these PBA textures that do not require the influence of microbial activity, the most prominent of which are ambient inclusion trails (AITs) and alpharecoil track etching (ARTEs). AITs are tubules that form from the high pressure of the surrounding water forcing a small mineral into the glass, which would form a tubule. These features are often accompanied by longitudinal striations and small millstones at the terminus of the tubule (Pentesco, 2019). ARTEs, on the other hand, form when radioactive $U$ and $T h$ decay, producing weakness in the glass that water preferentially palagonitizes, forming granules initially and then developing into microtubules extending into the glass (French \& Blake, 2016). While both of these processes have merit, they do not adequately explain the PBA at Crazy Hills. The general lack of tubules, combined with the absence of both longitudinal striations and millstones in existing structures rules out the possibility of AITs. While ARTEs could explain the formation of the granules and bubbles/buds, the pillows are neither radioactive or old enough for the ARTEs to carve into the glass. Furthermore, the Crazy Hills would have been part of an ephemeral systemthe hosting glacier and by extension the source of meltwater would have retreated from the region long before the ARTEs could create tubules. Neither of these explanations can adequately explain the conical intrusions, either. The initial widening of the base and undulating grooves present in some conical intrusions is more reflective of biogenic alteration than AITs or ARTEs.

\section{Preliminary Conclusions}

Field observations indicate the Crazy Hills and Lone Butte erupted under an ice sheet greater than $300 \mathrm{~m}$ thick, producing pillow lavas at the Crazy Hills and thick hyaloclastite deposits at Lone 
Butte. Estimation of the thickness of the overlying ice is not possible from lithofacies analysis. XRF results show that the two volcanic provinces may share a magma source in the mantle, but the two provinces have evolved separately. The CHB fractionated olivine out of the parental magma, while both provinces fractionated iron oxide out. Petrographic analysis shows resorption textures in many of the olivine crysts, indicating a mafic recharge event and emphasizing the dynamic nature of the ascending magma. Further petrographic analysis of the pillow rims from the Crazy Hills yielded PBA textures that are potentially biogenic. While abiogenic processes have not been ruled out, the identification and morphology of conical intrusions does not concur with abiogenic causes but fits better with biogenic activity. The preservation potential of these textures bodes well for Martian glaciovolcanoes, where the conditions are more static than on Earth.

Future work will include electron microprobe analyses on fresh glass pieces and water content analyses through FT-IR to better describe the thickness and characteristics of the overlying ice. Pillow rims will also undergo SEM analysis to characterize the chemistry of the PBA textures. Samples will also be Ar-Ar dated to better understand the timing of the glaciation that influenced the formation of these volcanic provinces.

\section{Acknowledgements}

My advisor Barry Cameron was instrumental in this work, and continues to be immensely helpful in the lab and out of it. Many thanks to my committee Lindsay McHenry, Julie Bowles, and John Isbell for their advice, and thanks to Adam Chumley for assistance in the field.

\section{References}

Ackiss, S., Horgan, B., Seelos, F., Farrand, W., \& Wray, J. (2018). Mineralogic evidence for subglacial volcanism in the Sisyphi Montes region of Mars. Icarus, 311, 357-370. https://doi.org/10.1016/j.icarus.2018.03.026

Bacon, C. R., \& Lanphere, M. A. (2006). Eruptive history and geochronology of Mount Mazama and the Crater Lake region, Oregon. Bulletin of the Geological Society of America, 118(11-12), 1331-1359. https://doi.org/10.1130/B25906.1

Bibring, J.-P., Langevin, Y., Mustard, J. F., Poulet, F., Arvidson, R., Gendrin, A., ... Omega team. (2006). Global Mineralogical and Aqueous Mars History Derived from OMEGA/Mars Express Data. Science, 312(April), 400-404.

Booth, D. B., Troost, K. G., Clague, J. J., \& Waitt, R. B. (2003). The Cordilleran Ice Sheet. Developments in Quaternary Science, 1(C), 17-43. https://doi.org/10.1016/S1571-0866(03)01002-9

Cousins, C. R., Crawford, I. A., Carrivick, J. L., Gunn, M., Harris, J., Kee, T. P., ... Joy, K. H. (2013). Glaciovolcanic hydrothermal environments in Iceland and implications for their detection on Mars. Journal of Volcanology and Geothermal Research, 256, 61-77. https://doi.org/10.1016/j.jvolgeores.2013.02.009

Cousins, Claire R., \& Crawford, I. A. (2011). Volcano-Ice Interaction as a Microbial Habitat on Earth and Mars. Astrobiology, 11(7), 695-710. https://doi.org/10.1089/ast.2010.0550

Fisk, M., \& McLoughlin, N. (2013). Atlas of alteration textures in volcanic glass from the ocean basins. Geosphere, 9(2), 317-341. https://doi.org/10.1130/GES00827.1

French, J. E., \& Blake, D. F. (2016). Discovery of Naturally Etched Fission Tracks and Alpha-Recoil Tracks in Submarine Glasses: Reevaluation of a Putative Biosignature for Earth and Mars. International Journal of Geophysics, 2016. https://doi.org/10.1155/2016/2410573

Ghatan, G. J., \& Head, J. W. (2002). Candidate subglacial volcanoes in the south polar region of Mars: Morphology, 
morphometry, and eruption conditions. Journal of Geophysical Research, 107(E7).

https://doi.org/10.1029/2001JE001519

Hammond, P. E. (1987). Lone Butte and Crazy Hills: subglacial volcanic complexes, Cascade Range, Washington. Geological Society of America Centennial Field Guide - Cordilleran Section, 1, 339-344.

Jakobsson, S. P., \& Gudmundsson, M. T. (2008). Subglacial and intraglacial volcanic formations in Iceland. Jokull, $58,179-196$.

Lanagan, P. D., McEwen, A. S., Keszthelyi, L. P., \& Thordarson, T. (2001). Rootless cones on Mars indicating the presence of shallow equatorial ground ice in recent times. Geophysical Research Letters, 28(12), 2365-2367. https://doi.org/10.1029/2001GL012932

Lescinsky, T., \& Fink, H. (2000). Glacial Extents and Future Volcanic Hazards, 105.

McHenry, L. J., Carson, G. L., Dixon, D. T., \& Vickery, C. L. (2017). Secondary minerals associated with Lassen fumaroles and hot springs: Implications for martian hydrothermal deposits. American Mineralogist, 102(7), 1418-1434. https://doi.org/10.2138/am-2017-5839

O’Hara, D., Karlstrom, L., \& Ramsey, D. (2020). Time-evolving surface and subsurface signatures of Quaternary volcanism in the Cascades arc. Geology, $X X(\mathrm{Xx}), 1-6$. https://doi.org/10.1130/G47706.1

Pentesco, J. T. (2019). Assessing environmental controls for candidate microbial ichnofossils in hydrothermally altered basaltic tuffs of Upsal Hogback, $N V$. Brock University.

Russell, J. K., Edwards, B. R., Porritt, L., \& Ryane, C. (2014). Tuyas: A descriptive genetic classification. Quaternary Science Reviews, 87, 70-81. https://doi.org/10.1016/j.quascirev.2014.01.001

Scanlon, K. E., Head, J. W., Wilson, L., \& Marchant, D. R. (2014). Volcano-ice interactions in the Arsia Mons tropical mountain glacier deposits. Icarus, 237, 315-339. https://doi.org/10.1016/j.icarus.2014.04.024

Schmidt, M. E., \& Grunder, A. L. (2009). The evolution of North Sister: A volcano shaped by extension and ice in the central Oregon Cascade Arc. Bulletin of the Geological Society of America, 121(5-6), 643-662. https://doi.org/10.1130/B26442.1

Skilling, I. P. (2009). Subglacial to emergent basaltic volcanism at Hlodufell, south-west Iceland: A history of iceconfinement. Journal of Volcanology and Geothermal Research, 185(4), 276-289. https://doi.org/10.1016/j.jvolgeores.2009.05.023

Smellie, J. L., \& Edwards, B. R. (2016). Glaciovolcanism on Earth and Mars: products, processes, and paleoenvironmental significance (First). Cambridge: Cambridge University Press.

Stevenson, J. A., Smellie, J. L., McGarvie, D. W., Gilbert, J. S., \& Cameron, B. I. (2009). Subglacial intermediate volcanism at Kerlingarfjöll, Iceland: Magma-water interactions beneath thick ice. Journal of Volcanology and Geothermal Research, 185(4), 337-351. https://doi.org/10.1016/j.jvolgeores.2008.12.016

Wilson, A., \& Russell, J. K. (2018). Quaternary glaciovolcanism in the Canadian Cascade volcanic arc paleoenvironmental implications, 2538(06). https://doi.org/10.1130/2018.2538(06) 